\section{KẾT LUẬN}

- Nghiên cứu mô tả cắt ngang 451 NB có chỉ định mổ theo kế hoạch, tại các khoa thuộc khối Ngoại - BVĐK tỉnh Sơn La; năm 2017.

- Điều dưỡng viên các khoa Ngoại đã rất tốt cho NB trước mổ như: tiếp đón; hỏi bệnh; hướng dẫn làm xét nghiệm; vệ sinh các nhân trước mổ.

- Nội dung điều dưỡng viên các khoa làm chưa tốt: Vệ sinh, sát khuẩn vùng sẽ mổ

- Đề xuất giải pháp: Bệnh viện cần thường xuyên kiểm tra, giám sát, đôn đốc thực hiện các quy định về chuẩn bị người NB nhiễm khuẩn; NB trước, trong và sau phẫu thuật.

\section{TÀI LIÊU THAM KHẢO}

1. Bênh viên đa khoa Tỉnh Sơn La, Phiếu chuẩn bị bệnh nhẩn trước mổ của điều dưỡng.

2. Trường đại học $Y$ Hà Nội - Bộ môn Gây mê hôi sức (2002), Bài giảng Gây mê hồi sức tập 1, Nhà xuất bản $Y$ hoc

3. Trường Cao đẳng Kỹ thuật $Y$ tế 1- Bộ $Y$ tế (2004), Gây mê gây tê cơ bản, Nhà xuất bản Y học

4. Bệnh việ̂n Trung Ương quân đội 108 (2015), Hướng dẫn quy định chuẩn bị người bệnh trước phẩu thuât

5. Chi hội Điêuu dưỡng Ngoại khoa Việt Nam, Chuẩn bị bệnh nhân trước mổ, Web - dieuduong ngoại.com

6. Bệnh viện 103, Bài giảng chuyên ngành GMHS chuẩn bi bệnh nhân trước mổ công tác điều dưỡng về chăm sóc người bệnh trong bệnh viện.

7. Đoàn Quốc Hưng và CS (2014), Nhận xét quy trình chuẩn bi bểnh nhân trước mổ tim hở có chuẩn bị ở người trưởng thành tại khoa PTTM-LNBV Hữu Nghi Việt Đức, Tap chí Tím Mach học Việt Nam số 63-2014

8. Bùi Thị Huyền, Đánh giá thực trang chuẩn bi và bàn giao người bệnh trước phẫu thuật tại khoa phấu thuât - GMḦS bênh viên Quân Y $3 \dot{5} 4$ năm 2015, http://www.benhvien103.vn

\title{
ĐÁNH GIÁ THỰC TRANG VỀ TIÊM AN TOÀN CỦA ĐIỀU DƯỠNG VIÊN TẠI MộT SỐ KHOA CỦA BÊ̂NH VIÊ̂N 198 Bộ CÔNG AN NĂM 2014
}

\section{TÓM TẮT}

Muc tiêu: Xác đinh tỷ lệ tiêm an toàn và một số yếu tổ liên quan tới tiêm an toàn của điêu dưỡng các khoa Hồi sức, Cấp cứu và khối Ngoại bệnh viện 19-8 Bộ Công An - năm 2014. Đối tượng và phương pháp: Nghiên cứu mô tả cắt nganğ; 85 điều dướng thực hiện 425 mũi tiêm cho bệnh nhân, thuộc các khoa Hổi sức, Cấp cứu và khối N̉goại bệnh viện 19-8 Bộ Công An -năm 2018. Quan sát xác định các mũi tiểm an toàn/ không an toàn dựa vào 17 Tiêu chuẩn Tiêm an toàn của Bộ Y tế. Kết qủa và kết luận: Tỷ lệ thực hiện mũi tiềm an toàn của điều dưỡng (mổi mũi tiêm đều thực hiện đúng 17 tiêu chuẩn Tiêm an toàn) là $39,76 \% ; 60,24 \%$ mũi tiêm được xác định không an toàn do không thực hiên/ hoặc thực hiên chưa đúng ít nhất 01 tiêu chuẩn Tiêm an toàn đã được Bô Y tế quy đinh. Môtt số yếu tố liên quan là: Điều dưỡng ở nhóm tuổi 41-50 có tỷ lệ thực hiện Tiêm an toàn cao nhất - 75\%; nhóm tuổi > 50 có tỷ lệ Tiêm an toàn thấp nhất: chiếm 20\%. Điều dưỡng thuộc khoa Hồi sức có tỷ lệthực hiên mũi Tiêm an toàn cào nhất: 57,5\%, khoa Ngoại Tổng hợp có tỷ lệ tiêm an toàn thấp nhất: $21,82 \%$.

\section{*Trường Đại học Kỹ thuật y tế Hải Dương \\ **Trường Đại học Thành Đông}

Chịu trách nhiệm chính: Phạm Thị Nhuyên

Email: nhuyenmd@yahoo.com.vn

Ngày nhận bài: 1/12/2020

Ngày phản biện khoa họ: $5 / 1 / 2021$

Ngày duyệt bài: 28/1/2021
Giang Thị Hằng*, Huỳnh Thị Bình*, Phạm Thị Nhuyên*, Nguyễn Duy Bảo**

Tư khóa: Điều dưỡng viên, tiêm an toàn

\section{SUMMARY}

DETERMINING THE SITUATION OF SAFE

INJECTION OF NURSES AT HOSPITAL 19-8

MINISTRY OF PUBLIC SECURITY - 2014

Objective: Determine safe injection rates and a number of factors related to safe injections of nurses in resuscitation, emergency and external hospitals 198 Ministry of Public Security - 2014. Subjects and research methods:Cross-sectional descriptive studies; 85 nurses performed 425 injections for patients, belonging to resuscitation departments, emergency department and external hospital block 198 Ministry of Public Security - 2014. Observed and identified safe / unsafe injections based on 17 Safety Injection Standards of the Ministry of Health. Results and Discussion: The rate of implementing safe injections of nurses (each injection is correctly implemented 17 standards of Safe Injections) is $39.76 \%$; $60.24 \%$ of the injections are considered unsafe due to failure to / or improper implementation of at least 1 standard of Safe Injections set by the Ministry of Health. Some related factors are: Nurses in the age group 41-50 have the highest rate of safe injection - 75\%; the age group > 50 has the lowest rate of Safe Injection: $20 \%$. Nurses in the Department of Rehabilitation have the highest rate of safe injections: $57.5 \%$, General Surgery has the lowest safe injection rate: $21.82 \%$.

Keywords: Nurses, safe injection 


\section{I. ĐĂT VẤN ĐỀ}

Tiêm là đương dùng thuốc rất quan trọng và hiệu quả trong điêu trị bệnh tại các bệnh viện và đặc biệt là những nơi có nhiêu người bệnh nặng. Trong lĩnh vực phòng bệnh, tiêm chủng đã tác đông manh vào viêc giảm tỷ lệ mắc đối với các bệnh lây có thể phò̀ng bằng vacxin ở các lứa tuổi $[5,6]$. Bên cạnh những ưu điểm trên, tiêm cũng có thể gây ra những nguy cơ như áp xe tại vị trí tiêm, chứng liệt thần kinh, phản ứng dị ứng, sốc phản vệ, đặc biệt là những nguy cơ truyền các virus qua đường máu cho cả người bệnh (NB), nhân viên y tế (NVYT) và cộng đồng $[5,6]$. WHO ước tính có tới $50 \%$ các mũi tiêm ở các nước đang phát triển không an toàn, có tới $20-80 \%$ các trường hợp nhiễm virus viêm gan $B$ là do tiêm không an toàn [7].

Tại Việt Nam, nhận thức về tầm quan trọng của tiêm an toàn và các nguy cơ do tiêm khổng an toàn gây nên. Năm 2000, Bộ y Tế đã phối hợp với Hội điều dưỡng Viêt nam phát động, triển khai chương trình "Tiểm an toàn" trong toàn quốc. Tuy nhiên, kết quả từ một số nghiên cứu cho thây tỷ lệ mũi tiêm đạt đủ các tiêu chuẩn tiêm an toàn còn chưa cao, dao động từ $6 \%$ đến $22,6 \%$ [1]. Các nguyên nhân dẫn đến tỷ lệ mũi tiêm an toàn thấp là: Điều dưỡng còn thiếu và chưa được cập nhật thông tin về tiêm an toàn; chưa tuân thủ đúng quy trình kỹ thuật và các thao tác kiểm soát nhiễm khuẩn trong thực hành tiêm, trong thu gom, xử lý và quản lý chất thải y tế sắc nhọn [2].

Bệnh viện 19.8 là Bệnh viện đa khoa hạng $\mathrm{I}$, đầu ngành của $Y$ tế CAND, với quy mố 600 giường bệnh, 41 khoa, phòng, trung tâm, với gần 1000 cán bộ chiến sỹ, công nhân viên. Bệnh viện có nhiệm vụ khám chữa bệnh cho cán bộ chiến sỹ, công nhân viên công an, đối tượng bảo hiểm và nhân dân, tham gia y tế cộng đồng, nghiên cứu khoa học, chỉ đạo tuyến, làm nhiệm vụ quốc tế và các nhiệm vụ khác do lãnh đạo Bộ Công an, Tổng cục Hậu cần - Kỹ thuật giao phó[8]. Với xu hướng phát triển chung của xã hội bệnh viện luôn đâuu tư cải thiện, nâng cao chất lượng. Tiêm an toàn đã được BV thực hiện ngay từ khi chương trình "tiêm an toàn" được Hôi Điều dưỡng Viêt Nam phát động. Để góp phần mô tả thực trạng vấn đề này và hơn nữa, tiêm là kỹ thuật phổ biến mà điều dưỡng thực hiện mỗi ngày, vì vậy trong thời gian đi thực tế tốt nghiệp tại bệnh viên 198 tôi tiến hành nghiên cứu "Đánh giá thực trạng về tiêm an toàn của Điều dưỡng viên tại một số khoa của Bệnh viện 198 - Bộ Công an năm 2014"nhằm mục tiêu:
1. Xác định tỷ lệ tiêm an toàn của điều dưỡng viên tại khoa Hồi sức, Cấp cứu và khối Ngoại bệnh viện 19-8, năm 2014.

2. Mô tả một số yếu tố liên quan tới tiêm an toàn của điều dưỡng viên tại khoa Hồi sức, Cấp cứu và khôi Ngoại, Bệnh viện 19- 8.

\section{II. ĐỐI TƯƠNGG VÀ PHƯƠNG PHÁP NGHIÊN CỨU}

2.1. Đối tượng: Điều dưỡng hiện đang công tác tại các khoa Hồi sức, Cấp cứu và khối Ngoại trong Bệnh viện 19-8, tự nguyện tham gia nghiên cứu. Các mũi tiêm được thực hiện bởi điều dưỡng viên trên người bệnh nội trú tại các khoa Hồi sức, Cấp cứu và khối Ngoại Bệnh viện 198.

2.2. Thiết kế nghiển cứu: Nghiên cứu mô tả cắt ngang có phân tích

2.3. Chọn mẫu và cỡ mẫu. Số mũi tiêm cần quan sát: Áp dụng công thức tính cỡ mẫu

$$
n=\frac{z^{2} 1-a / 2 p(1-p)}{d^{2}}
$$

Trong đó: $\mathrm{n}$ là số mũi tiêm tối thiểu cần quan sát; z1- a/2: Hệ số tin cậy, kiểm định 2 phía (= $1,96)$; a: Mức ý nghĩa $(=0,05)$

p: Ước lượng tỷ lệ mũi tiêm an toàn cho các bệnh viện Hà nội dựa vào nghiên cứu của Nguyễn Thị Dung năm 2009 tại BVĐK Hà Đông tỷ lệ tiêm an toàn của bệnh viện là $51,2 \%$ [5], trong nghiên cứu này để cỡ mẫu bao phủ, $p=0,5$

d: Sai số chấp nhận được của ước lượng ( $\mathrm{d}=$ 0,05). Theo cách tính trên: $\mathrm{n}=384$ mũi tiêm.

Số điều dưỡng thực hiện các mũi tiêm: theo danh sách tổng hợp của bệnh viện, tổng số điều dưỡng tại các khoa Hồi sức, Cấp cứu và khối Ngoại trực tiếp tham gia thực hành tiêm có 85 điêu dướng. Nghiên cứu chọn toàn bộ 85 điều dưỡng. Trong tổng số 384 mũi tiêm (kết quả tính ở trên), ước tính tỷ lệ không quan sát toàn bộ quy trình được là $10 \%$ (38mũi tiêm), vậy cõ̃ mẫu cân thu thập là: $n=384+38=422$ mũi tiêm. Mỗi điều dương cần quan sát 422: $85=4,96$ làm tròn thành 5 mũi tiêm/ một điều dưỡng.

Tổng số mũi tiêm cần quan sát là $85 \times 5=425$ mũi tiêm. Các mũi tiêm được chọn như sau: 33 điều dưỡng chỉ quan sát tiêm TM (trực tiếp), 17 điêu dưỡng chỉ quan sát tiêm TM qua chạc $\mathrm{ba/catheter,} 14$ điêu dưỡng chỉ quan sát tiêm bắp, 10 điều dưỡng chỉ quan sát tiêm dưới da và 11 điều dương chỉ quan sát tiêm trong da.

2.4. Công cụ đánh giá, tiêu chí đánh giá. Quan sát 425 mũi tiêm do 85 điều dưỡng thực hiện trên người bệnh, bao gồm tiêm tĩnh mạch trực tiếp, Tiêm TM qua chạc 3/catheter, tiêm bắp, tiêm dưới da, tiêm trong da. Mỗi điều dưỡng sẽ được quan sát 5 mũi tiêm. 
Quan sát dựa vào 17 tiêu chuẩn Tiêm an toàn của Bộ Y Tế và Hội điều dưỡng Việt nam [3,4].

- Mũi tiêm an toàn: là mũi tiêm thực hiện đúng 17 tiêu chuẩn Tiêm an toàn,

- Mũi tiêm không an toàn: nếu thực hiên không đúng ít nhất 01/17 tiêu chuẩn Tiêm an toàn.

\subsection{Thời gian và địa điểm nghiên cứu}

- Đia điểm: Bênh viên 198 bộ Công An

- Thời gian: năm 2014

2.6. Xử lý số liệu: Sử dụng phần mềm thống kê SPSS 16.0

\section{KẾT QUẢ NGHIÊN CỨU}

3.1. Đăc điểm chung của đối tượng nghiên cứu

Bảng 3.1.1. Giới của đối tượng nghiên cứu

\begin{tabular}{|c|c|c|c|}
\hline Giới & Nam & Nữ & Tống \\
\hline Số lượng (n) & 18 & 67 & 85 \\
\hline Tỷ lệ $(\%)$ & 21,2 & 78,8 & 100 \\
\hline
\end{tabular}

Nhần xét: Điều dưỡng Nữ chiếm tỷ lệ cao (78,8\%) hon Nam

Bảng 3.1.2. Tuổi của đối tượng nghiên cứu

\begin{tabular}{|c|c|c|}
\hline Tuối & Số lượng (n) & Tỳ lệ (\%) \\
\hline$<=30$ & 52 & 61,2 \\
\hline $30-40$ & 25 & 29,4 \\
\hline $41-50$ & 4 & 4,7 \\
\hline$>50$ & 4 & 4,7 \\
\hline Tống & $\mathbf{8 5}$ & $\mathbf{1 0 0}$ \\
\hline
\end{tabular}

Nhận xét: Điều dưỡng < =30 tuối chiếm tỳ lệ cao $61,2 \%$

Bảng 3.1.3. Thâm niên công tác

\begin{tabular}{|c|c|c|}
\hline $\begin{array}{c}\text { Thâm niên công } \\
\text { tác }\end{array}$ & $\begin{array}{c}\text { Số lượng } \\
\text { (n) }\end{array}$ & $\begin{array}{c}\text { Tỷ lệ } \\
\mathbf{( \% )}\end{array}$ \\
\hline$<5$ năm & 53 & 62,35 \\
\hline $5-10$ năm & 18 & 21,18 \\
\hline Trên 10 năm & 14 & 16,47 \\
\hline Tống & $\mathbf{8 5}$ & $\mathbf{1 0 0}$ \\
\hline
\end{tabular}

Nhận xét: Điều dưỡng thâm niên < 5 năm chiếm tỷ lệ cao $62,35 \%$

Bảng 3.4. Trinh độ chuyên môn của đổi tượng nghiên cứu

\begin{tabular}{|c|c|c|}
\hline $\begin{array}{c}\text { Trình độ } \\
\text { chuyên môn }\end{array}$ & $\begin{array}{c}\text { Số lượng } \\
\text { (n) }\end{array}$ & Tỷ lệ(\%) \\
\hline Đại học & 9 & 10,59 \\
\hline Cao đắng & 9 & 10,59 \\
\hline Trung cấp & 67 & 78,82 \\
\hline Tống & $\mathbf{8 5}$ & $\mathbf{1 0 0}$ \\
\hline
\end{tabular}

Nhận xét: Điều dưỡng Trung cấp chiếm tỷ lệ cao $78,82 \%$ tiêm

Bảng 3.1.5. Số lượng mũi tiêm theo đường

\begin{tabular}{|c|c|c|}
\hline Khảo sát & Số lượng & Tỷ lệ (\%) \\
\hline Tiêm TM trực tiếp & 165 & 38,82 \\
\hline $\begin{array}{c}\text { Tiêm TM qua chạc } \\
\text { 3/ catheter }\end{array}$ & 85 & 20 \\
\hline Tiêm bắp & 70 & 16,47 \\
\hline Tiêm dưới da & 50 & 11,76 \\
\hline Tiêm trong da & 55 & 12,94 \\
\hline Tống & $\mathbf{4 2 5}$ & $\mathbf{1 0 0}$ \\
\hline
\end{tabular}

Nhận xét: Tiêm tĩnh mạch trực tiếp chiếm tỳ lệ cao $38,82 \%$

Bảng 3.1.6. Phân bố mũi tiêm quan sát ở các khoa

\begin{tabular}{|c|c|c|}
\hline Khoa & $\begin{array}{c}\text { Số mũi } \\
\text { tiêm } \mathbf{( n )}\end{array}$ & $\begin{array}{c}\text { Tỷ lệ } \\
(\mathbf{\%})\end{array}$ \\
\hline Cấp cứu & 115 & 27,06 \\
\hline Hồi sức & 80 & 18,82 \\
\hline Ngoại Tống Hợp & 55 & 12,94 \\
\hline Ngoại Tiết niệu & 55 & 12,94 \\
\hline Ngoại Phâuu thuật thần kinh & 70 & 16,47 \\
\hline $\begin{array}{c}\text { Ngoại chấn thương chỉnh } \\
\text { hình- Bỏng }\end{array}$ & 50 & 11,76 \\
\hline Tống & $\mathbf{4 2 5}$ & $\mathbf{1 0 0}$ \\
\hline
\end{tabular}

Nhận xét: Khoa Cấp cứu có số mũi tiêm nhiều nhất 27,06\%

3.2. Mũi tiêm thực hành đúng các tiêu chuẩn tiêm an toàn

Bảng 3.2.1. Tỷ lể mũi tiêm thực hiện các tiêu chuẩn của tiêm an toàn

\begin{tabular}{|c|c|c|c|c|}
\hline \multirow{2}{*}{17 Tiêu chuẩn TAT } & \multicolumn{2}{|c|}{ Thức hiên } & \multicolumn{2}{|c|}{ Không thực hiên } \\
\hline & Số lần (n) & Tỷ lệ (\%) & Số lần (n) & Tỷ lề (\%) \\
\hline Bơm kim tiêm vô khuẩn. & 387 & 91,06 & 38 & 8,94 \\
\hline Có sử dụng xe tiêm khi đi tiêm. & 348 & 81,88 & 77 & 18,12 \\
\hline Có sử dung khay tiêm khi đi tiêm. & 335 & 78,82 & 90 & 21,18 \\
\hline Có hộp đựng vật sắc nhọn ở gần nơi tiêm. & 318 & 74,82 & 107 & 25,18 \\
\hline Rửa tay, sát khuấn tay nhanh trước khi chuẩn bị thuốc. & 332 & 78,12 & 93 & 21,88 \\
\hline $\begin{array}{l}\text { Rửa tay, sát khuẩn tay nhanh trước khi đưa kim } \\
\text { qua da. }\end{array}$ & 307 & 72,24 & 118 & 27,76 \\
\hline Mang găng khi tiêm. & 297 & 69,88 & 128 & 30,12 \\
\hline Kim lấy thuốc đảm bảo vô khuẩn. & 385 & 90,59 & 40 & 9,41 \\
\hline Tiêm thuốc đúng chỉ đinh. & 396 & 93,18 & 29 & 6,82 \\
\hline Tiêm thuốc đúng thời gian. & 361 & 84,94 & 64 & 15,06 \\
\hline
\end{tabular}




\begin{tabular}{|c|c|c|c|c|}
\hline Tiêm đúng vị trí. & 365 & 85,88 & 60 & 14,12 \\
\hline Tiêm đúng góc kim so với mặt da. & 342 & 80,47 & 83 & 19,53 \\
\hline Tiêm đúng độ sâu. & 318 & 74,82 & 107 & 25,18 \\
\hline Rút pit tông kiểm tra trước khi bơm thuốc. & 338 & 79,53 & 87 & 20,47 \\
\hline Bơm thuốc đảm bảo hai nhanh một chậm. & 358 & 84,24 & 67 & 15,76 \\
\hline Không dùng hai tay đậy nắp kim. & 331 & 77,88 & 94 & 22,12 \\
\hline $\begin{array}{c}\text { Cô lập ngay bơm kimm tiêm đã nhiếm khuẩn } \\
\text { trong hộp an toàn. }\end{array}$ & 337 & 79,29 & 88 & 20,71 \\
\hline
\end{tabular}

Nhận xét: Bảng 3.2.1 cho thấy tỷ lệ thực hiện tiêu chí 1 (bơm kim tiêm vô khuẩn) là $91,09 \%$, tỷ lệ thực hiện tiêu chí 8 (kim lấy thuốc vô khuẩn) là 90,59\%.

Bảng 3.2.2. Tỷ lê số mũi tiêm đạt đủ các tiêu chuẩn tiêm an toàn của mối điều dưỡng

\begin{tabular}{|c|c|c|}
\hline $\begin{array}{c}\text { Số mũi tiêm đât đủ } \\
\text { các tiêu chuẩn TAT }\end{array}$ & $\begin{array}{c}\text { Số lượng } \\
\text { (n) }\end{array}$ & $\begin{array}{c}\text { Tỷ lề } \\
(\mathbf{\%})\end{array}$ \\
\hline $5 / 5$ & 5 & 5,9 \\
\hline $4 / 5$ & 7 & 8,2 \\
\hline $3 / 5$ & 13 & 15,3 \\
\hline $2 / 5$ & 19 & 22,4 \\
\hline $1 / 5$ & 39 & 45,9 \\
\hline $0 / 5$ & 2 & 2,4 \\
\hline Tống & $\mathbf{8 5}$ & $\mathbf{1 0 0}$ \\
\hline
\end{tabular}

Nhân xét: Chỉ có 5 điều dưỡng có cả 5 mũi tiêm đạt đủ các tiêu chí tiêm an toàn (5,9\%). Số lượng điều dưỡng thực hiện 1 mũi tiêm đạt đủ

các tiêu chí của tiêm an toàn trong 5 mũi tiêm được quan sát là 39 và chiếm tỷ lệ cao nhất $(45,9 \%)$.

Bảng 3.2.3. Tỷ lệ mũi tiêm an toàn

\begin{tabular}{|c|c|c|}
\hline & Số lượng (n) & Tỷ lệ (\%) \\
\hline Tiêm an toàn & 169 & $\mathbf{3 9 , 7 6}$ \\
\hline Tiêm không an toàn & 256 & 60,24 \\
\hline Tống & $\mathbf{4 2 5}$ & $\mathbf{1 0 0}$ \\
\hline
\end{tabular}

Nhận xét: Tỷ lệ mũi tiêm an toàn thấp hơn nhiều $(39,76 \%)$ so với mũi tiêm không an toàn $(60,24 \%)$

3.3. Một số yếu tố liên quan tới tiêm an toàn của điều dưỡng tại khoa hồi sức, cấp cứu và khối Ngoại, Bệnh viện 198

Bảng 3.3.1. Tý lệ tiêm an toàn theo giới

\begin{tabular}{|c|c|c|c|c|c|}
\hline \multicolumn{2}{|c|}{ Giới } & Tiêm an toàn & Tiêm không an toàn & Tống & P \\
\hline \multirow{2}{*}{ Nam } & Tần số $(\mathrm{n})$ & 38 & 52 & 90 & \\
\cline { 2 - 6 } & Tỷ lệ $(\%)$ & 42,22 & 57,78 & 100 & \multirow{2}{*}{0,644} \\
\multirow{2}{*}{ Nữ } & Tần số $(\mathrm{n})$ & 131 & 204 & 335 & \\
\cline { 2 - 6 } & Tý lệ $(\%)$ & 39,1 & 60,9 & 100 & \\
\hline
\end{tabular}

Nhận xét: Tỷ lệ tiêm an toàn giới nam (42,22\%) cao hơn nữ (39,10\%). Tuy nhiên, sự khác nhau này không có ý nghĩa thống kê $(p>0,05)$.

Bảng 3.3.2. Tý lệ tiêm an toàn theo tuổi

\begin{tabular}{|c|c|c|c|c|c|}
\hline \multicolumn{2}{|c|}{ Tuối } & Tiêm an toàn & Tiêm không an toàn & Tống & $\mathbf{p}$ \\
\hline \multirow{2}{*}{$\leq 30$} & Tần số (n) & 102 & 158 & 260 & \multirow{8}{*}{0,013} \\
\hline & Tỷ lệ (\%) & 39,23 & 60,77 & 100 & \\
\hline \multirow{2}{*}{$31-40$} & Tần số $(\mathrm{n})$ & 48 & 77 & 120 & \\
\hline & Tỷ lệ (\%) & 38,4 & 61,6 & 100 & \\
\hline \multirow{2}{*}{$41-50$} & Tần số $(n)$ & 15 & 5 & 20 & \\
\hline & Tỷ lệ (\%) & 75 & 25 & 100 & \\
\hline \multirow{2}{*}{$>50$} & Tần số (n) & 4 & 16 & 20 & \\
\hline & Tỷ lệ (\%) & 20 & 80 & 100 & \\
\hline
\end{tabular}

Nhận xét: Tỷ lệ tiêm an toàn cao nhất ở nhóm tuối 41-50 (75\%), thấp nhất là ở nhóm tuối > 50 $(20 \%)$, Sự khác biểt có ý nghĩa thống kê $(p<0,05)$.

Bảng 3.3.3. Tỷ lệ tiêm an toàn theo thâm niên công tác

\begin{tabular}{|c|c|c|c|c|c|}
\hline \multicolumn{2}{|c|}{ Thâm niên công tác } & Tiêm an toàn & Tiêm không an toàn & Tống & $\mathbf{p}$ \\
\hline -5 nา̆m & Tân số $(n)$ & 106 & 159 & 265 & \multirow{6}{*}{0,107} \\
\hline < s nam & Tỷ lệ (\%) & 40 & 60 & 100 & \\
\hline $5-10$ & Tần số (n) & 28 & 62 & 90 & \\
\hline năm & Tỷ lệ (\%) & 31,11 & 68,89 & 100 & \\
\hline \multirow{2}{*}{ >10 năm } & Tần số $(n)$ & 35 & 35 & 70 & \\
\hline & Tỷ lệ (\%) & 50 & 50 & 100 & \\
\hline
\end{tabular}

Nhận xét: Tỷ lệ tiêm an toàn ở nhóm có thâm niên công tác >10 năm là cao nhất (50\%), nhóm có thâm niên công tác từ 5 - 10 năm có tỷ lệ tiêm an toàn thấp nhất $(31,11 \%)$, nhóm có thâm niên 
công tác $<5$ năm có tỷ lệ tiêm an toàn là $40 \%$. Tuy nhiên, mối liên quan giữa tiêm an toàn và thâm niên công tác không có ý nghĩa thống kê ( $p>0,05)$.

Bản 3.3.4. Tỷ lê tiêm an toàn theo trinh độ chuyên môn

\begin{tabular}{|c|c|c|c|c|c|}
\hline \multicolumn{2}{|c|}{ Trình độ chuyên môn } & Tiêm an toàn & Tiêm không an toàn & Tống & $\mathbf{p}$ \\
\hline \multirow{2}{*}{ Đại học } & Tần số (n) & 18 & 27 & 45 & \multirow{6}{*}{0,133} \\
\hline & Tỷ lệ (\%) & 40 & 60 & 100 & \\
\hline \multirow{2}{*}{ Cao đằng } & Tần số $(\mathrm{n})$ & 25 & 20 & 45 & \\
\hline & Tỷ lê (\%) & 55,56 & 44,44 & 100 & \\
\hline \multirow{2}{*}{ Trung cấp } & Tần số $(\mathrm{n})$ & 126 & 209 & 335 & \\
\hline & Tỷ lê (\%) & 37,61 & 62,39 & 100 & \\
\hline
\end{tabular}

Nhânn xét: Cho thấy tỷ lệ tiêm an toàn ở trình độ chuyên môn Đai hoc chiếm $40 \%$, trình độ chuyên môn cao đẳng chiếm $55,56 \%$, trình độ chuyên môn trung cấp chiếm 37,61\%.

Bảng 3.3.5. Tý lệ tiêm an toàn theo đường tiêm

\begin{tabular}{|c|c|c|c|c|c|}
\hline \multicolumn{2}{|l|}{ Đưởng tiêm } & $\begin{array}{l}\text { Tiêm an } \\
\text { toàn }\end{array}$ & $\begin{array}{l}\text { Tiêm không } \\
\text { an toàn }\end{array}$ & Tổng & $\mathbf{p}$ \\
\hline \multirow{2}{*}{ Tiêm tĩnh mạch (trực tiếp) } & Tần số (n) & 67 & 98 & 165 & \multirow{10}{*}{0,698} \\
\hline & Tỷ lệ (\%) & 40,61 & 59,39 & 100 & \\
\hline \multirow{2}{*}{ Tiêm tĩnh mạch qua chạc ba/catheter } & Tần số $(\mathrm{n})$ & 15 & 70 & 85 & \\
\hline & Tỷ lệ (\%) & 17,65 & 82,35 & 100 & \\
\hline \multirow[b]{2}{*}{ Tiêm bắp } & Tần số (n) & 41 & 29 & 70 & \\
\hline & Tỷ lê (\%) & 58,57 & 41,43 & 100 & \\
\hline \multirow{2}{*}{ Tiêm dưới da } & Tần số $(n)$ & 22 & 28 & 50 & \\
\hline & Tỷ lê (\%) & 44 & 46 & 100 & \\
\hline \multirow{2}{*}{ Tiêm trong da } & Tần số (n) & 24 & 31 & 55 & \\
\hline & Tỷ lệ (\%) & 43,64 & 56,36 & 100 & \\
\hline
\end{tabular}

Nhận xét: Tỷ lệ tiêm an toàn theo đường tiêm cao nhất bằng đường tiêm bắp $(58,57 \%)$ và thấp nhất (17,65\%) là tiêm tĩnh mạch qua chạc ba (catheter).

Bảng 3.3.6. Tý lệ tiêm an toàn theo khoa

\begin{tabular}{|c|c|c|c|c|c|}
\hline Khoa & & Tiêm an toàn & Tiêm không an toàn & Tống & $\mathbf{p}$ \\
\hline \multirow{2}{*}{ Cấp cứu } & Tân số (n) & 35 & 80 & 115 & \multirow{12}{*}{0,02} \\
\hline & Tỷ lệ (\%) & 30,43 & 69,57 & 100 & \\
\hline \multirow{2}{*}{ hồi sức } & Tấn sồ (n) & 46 & 34 & 80 & \\
\hline & Tý lẹ (\%) & 57,5 & 42,5 & 100 & \\
\hline \multirow{2}{*}{ Ngoại tổng hợp } & Tần sồ (n) & 12 & 43 & 55 & \\
\hline & Tỷ lệ (\%) & 21,82 & 78,18 & 100 & \\
\hline \multirow{2}{*}{ Ngoại tiết niệu } & Tần số (n) & 25 & 30 & 55 & \\
\hline & Tý lề (\%) & 45,45 & 54.55 & 100 & \\
\hline \multirow{2}{*}{$\begin{array}{c}\text { Ngoại phâu thuật } \\
\text { thần kinh }\end{array}$} & Tần sồ (n) & 29 & 41 & 70 & \\
\hline & Tỷ lẹ (\%) & 41,43 & 58,57 & 100 & \\
\hline \multirow{2}{*}{$\begin{array}{l}\text { Ngoaai chấn thương } \\
\text { chỉnh hình-bỏng }\end{array}$} & Tần sồ (n) & 22 & 28 & 50 & \\
\hline & Tỷ lệ (\%) & 44 & 56 & 100 & \\
\hline
\end{tabular}

Nhân xét: Khoa Hồi sức có tỳ lệ tiêm an cao nhất so với các khoa nghiên cứu còn lại $(57,5 \%)$ và thấp nhất là khoa Ngoại tổng hợp (21,82\%). Sự khác nhau này không có ý nghĩa thống kê $(p<0,05)$.

\section{BÀN LUẬN}

Kết quả quan sát tại 6 khoa lâm sàng trong địa điểm nghiên cứu: chúng tôi nhận thấy điều dưỡng hầu hết là nữ $67 / 85$ (78,8\%). Điều dưỡng viên thuộc nhóm tuổi $\leq 30$ chiếm tỷ lệ cao nhất là $(61,2 \%)$. Điều dưỡng viên có thâm niên công tác trên 10 năm và chiếm tỷ lệ thấp nhất là $(16,47 \%)$. Trình độ chuyên môn trung cấp chiếm tỷ lệ cao nhất $(78,8 \%)$, cao đẳng và đại học có số lượng như nhau và đều chiếm $10,59 \%$. Do vậy, bệnh viện cũng đã tăng cường tuyển thêm một số lượng lớn các điều dưỡng trẻ từ các trường đại học, cao đẳng để đáp ứng được nhu cầu về sức khỏe hiện nay của nhân dân.

Với số lượng là 85 điều dưỡng, chúng tôi đã tiến hành quan sát 425 mũi tiêm theo cõ̃ mẫu, mỗi điều dưỡng được quan sát 5 mũi tiêm của cùng một đường tiêm khi điều dưỡng thực hiện trên các người bệnh điêu trị nội trú trong thời gian của năm 2014. Quan sát dựa theo 17 tiêu chí tiêm an toàn của Hội điều dưỡng Việt Nam thấy số mũi tiêm an toàn (mũi tiêm thực hiện 
đúng và đủ 17 tiêu chí) là 169 và tỷ lệ là $39,76 \%$, số mũi tiêm không an toàn (mũi tiêm không thực hiện $\geq 1$ tiêu chí trong 17 tiêu chí) là 256 và tỳ lệ là 60,24\%.

\section{KẾT LUẬN}

Qua kết quả khảo sát vê tiêm an toàn của 85 điêu dưỡng tại khoa Cấp cứu, Hồi sức và khối Ngoại Bệnh viện 19-8 Bộ công an, năm 2014, chúng tôi rút ra một số kết luận như sau:

- Tỷ lệ tiêm an toàn của điêu dưỡng: 39,76\%

- Các yếu tố liên quan:

+ Nhóm tuổi 41-50 có tỷ lệ TAT cao nhất: 75\%; nhóm tuổi > 50 có tỷ lệ TAT thấp nhất: chiếm $20 \%$

+ Khoa Hồi sức có tỷ lệ tiêm an toàn cao nhất: 57,5\%, khoa Ngoại Tổng hợp có tỷ lệ tiêm an toàn thấp nhất: $21,82 \%$.

\section{TÀI LIỆ THAM KHẢO}

1. Đào Thành (2010), "Kết quả nghiên cứu đánh giá thực trạng tiêm an toàn tại 13 bệnh viện lựa chọn năm 2013", Hôi Điều dương Viêt Nam.

2. Phạm Đức Mục ( 2005), "Đánh giá kiến thức về Tiểm an toàn và tân xuất rủi ro do vât sắc nhọn đối với Điêu dưỡng - Hộ sinh tại 8 Tỉnh đại diện, 6 tháng đâu năm 2005", Kỷ yếu đề tài nghiên cứu khoa hoc điều dưỡng toan quốc lần thứ II, Hội Điều dưỡng Việt Nam, Hà Nội, tr.224-232

3. Bô y tế vu khoa hoc và đào tao "Điều dưỡng cở bản", Nhà xuất bản y học, Hà Nội (2002), trang $160-190$.

4. Bộ y tế (2012), Hướng dẫn tiêm an toàn trong các cở sở khám bệnh, chữa bệnh, Hà Nội.

5. Phan Thi Dung (2009), Nghiên cứu khảo sát về tiêm an toàn tai bênh viên Viêtt Đức năm 2009, Hà Nôii

6. Tài liệu Hội nghi khoa hoc Điều dưỡng Bệnh viện Hữu nghi Viêt Đức lần thứ V, trang 23,33.

7. WHO, (2002), Department of Protection of the Human Environment và Department of Vaccines and Biologicals (2002), "First, do no harm"introducing auto-disable syringes and ensuring injection safety in immunization systems of developing countries, Geneva, Switzerland.

\section{TỶ LÊ THIẾU Cơ VÀ MộT SỐ YẾU Tố LIÊN QUAN TRÊN BỂNH NHÂN CAO TUỔI ĐÁI THÁO ĐƯỜ'NG TÍP 2}

\section{TÓM TẮT}

Muc tiêu: Xác đinh tỷ lê thiếu cơ và khảo sát môt số yếu tố liên quan đến thiếu cơ ở bệnh nhân cao tuổi ĐTĐ típ 2. Đối tượng và phương pháp: Thiết kế nghiên cứu là mô tả cắt ngang trên bệnh nhân $\geq 60$ tuổi có bệnh ĐTĐ típ 2 đến khám tại phòng khám ngoại trú bệnh viện Quân Y 175 trong khoảng thời gian từ tháng 11/2019 đến tháng 03/2020 thóa các tiêu chuẩn chọn mấu. Kết quả: Nghiên cứu này thu nhận 255 bệnh nhân với tuổi trung bình là 76,76 7,3 (tuổi), trong đó nam chiếm tỷ lệ $81,6 \%$. Tỷ lệ thiếu cơ chung trên các bệnh nhân có đái tháo đường là $22,7 \%$. Khi phân tích logistic đa biến, chúng tôi ghi nhận chỉ đặc điểm thời gian mắc bệnh đái tháo đường $(\mathrm{OR}=0,37, \mathrm{KTC} 95 \% 0,14-0,98, \mathrm{p}=0,045)$ và thể trang $(\mathrm{OR}=4,57, \mathrm{KTC} 95 \% 2,76-7,56, \mathrm{p}<0,001)$ là 2 yểu tố có liên quan với thiếu cơ. Kết luân: Thiếu cơ chiếm tỷ lệ khoảng gân $1 / 4$ dân số người cao tuổi bi đái tháo đường. Thời gian bi đái tháo đường và thể trạng là hai yếu tố có liên quan đến thiếu cơ.

Tư khóa: Thiếu cơ, người cao tuổi, đái tháo đường típ 2.

\footnotetext{
${ }^{1}$ Bệnh viện175, TP Hồ Chí Minh

${ }^{2}$ Đai học Y Dượ TP Hồ Chí Minh

${ }^{3}$ Bềnh viên Thống Nhất, TP Hồ Chí Minh

Chịu trách nhiệm chính: Nguyễn Văn Tân

Email: nguyenvtan10@ump.edu.vn

Ngày nhận bài: 3/12/2020

Ngày phản biên khoa hoc: 4/1/2021

Ngày duyệt bài: 29/1/2021
}

\section{SUMMARY \\ PREVALENCE AND SOME FACTORS RELATED TO SARCOPENIA IN ELDERLY PATIENTS WITH TYPE 2 DIABETES MELLITUS}

Objective: To determine the prevalence and investigate some factors related to sarcopenia in elderly patients with type 2 diabetes mellitus. Subjects and methods: research design was crosssectional description in patients $\geq 60$ years old with type 2 diabetes mellitus who visited the outpatient clinic at 175 Military Hospital from November 2019 to March 2020 with all patients who met the study inclusion criteria. Results: This study enrolled 255 patients with an average age of $76.76 \pm 7.3$ (age), of which the rate was $81.6 \%$ for men. The prevalence of sarcopenia in elderly patients with type 2 diabetes mellitus was $22.7 \%$. When analyzing multivariate logistic, we recorded only duration of diabetes mellitus (OR $=0.37,95 \%$ CI $0.14-0.98, p=0.045)$ and body mass index $(\mathrm{OR}=4.57,95 \%$ CI 2.76-7.56, $\mathrm{p}<0.001)$ were two factors associated with sarcopenia. Conclusion: sarcopenia accounted for nearly a quarter of the elderly patients with type 2 diabetes mellitus. Diabetes duration and body mass index were two factors related to sarcopenia.

Keywords: Sarcopenia, the elderly, type 2 diabetes mellitus.

\section{I. ĐặT VẤN ĐỀ}

Thiếu cơ (sarcopenia) đang trở thành một vẫn đề sức khỏe ngày càng phổ biến ở người 